\title{
Effect of treatment with human chorionic gonadotropin 7 days after artificial insemination or at the time of embryo transfer on reproductive outcomes in nulliparous Holstein heifers
}

\author{
A. M. Niles, H. P. Fricke, P. D. Carvalho, M. C. Wiltbank, L. L. Hernandez, and P. M. Fricke* \\ Department of Dairy Science, University of Wisconsin-Madison, Madison 53706
}

\begin{abstract}
Our objective was to assess the effect of treatment with human chorionic gonadotropin (hCG) $7 \mathrm{~d}$ after artificial insemination (AI) or at the time of in vitro-fertilized (IVF) embryo transfer on reproductive outcomes, including progesterone ( $\mathrm{P} 4)$, interferon-tau stimulated gene 15 (ISG15), pregnancy-specific protein $\mathrm{B}$ (PSPB), and pregnancies per AI (P/AI) or pregnancies per embryo transfer $(\mathrm{P} / \mathrm{ET})$, in nulliparous Holstein heifers. Heifers in experiment 1 were randomly assigned to receive no treatment (control; $\mathrm{n}=129$ ) or 2,000 IU of hCG $7 \mathrm{~d}$ after AI to a detected estrus (estrus $=$ experimental $\mathrm{d} 0 ; \mathrm{hCG} ; \mathrm{n}=132$ ). Heifers in experiment 2 were randomly assigned to receive no treatment (control; $\mathrm{n}=143$ ) or $2,000 \mathrm{IU}$ of $\mathrm{hCG}$ (hCG; $\mathrm{n}=148$ ) at transfer of an IVF embryo $7 \mathrm{~d}$ after the last GnRH treatment of a 5-d controlled internal drug release-synch protocol (last $\mathrm{GnRH}=$ experimental $\mathrm{d}$ $0)$. Blood samples were collected from a subgroup of heifers (experiment $1, \mathrm{n}=82$; experiment $2, \mathrm{n}=104$ ) at $\mathrm{d} 7,11,18,20,25,28$, and 32 , and blood samples from heifers diagnosed pregnant were collected on d 35, $39,46,53,60$, and 67 . Blood samples were assayed for P4 by RIA and for PSPB by ELISA, and expression of ISG15 was assessed in mRNA isolated from blood leukocytes on d 18 and 20. Data were analyzed by ANOVA and logistic regression using the MIXED and GLIMMIX procedures. In both experiments, treatment with hCG increased $\mathrm{P} 4$ concentrations from d 11 to 32; however, treatment did not affect $\mathrm{P} / \mathrm{AI}$ or $\mathrm{P} / \mathrm{ET}$ at d 32 or 67 , PSPB concentrations from d 11 to 67 of pregnancy, or relative $I S G 15 \mathrm{mRNA}$ concentrations on d 18 or 20. Heifers diagnosed not pregnant at d 32 in experiment 2 with an extended luteal phase $(>20$ d) and treated with hCG had greater relative ISG15
\end{abstract}

Received August 23, 2018.

Accepted November 27, 2018.

*Corresponding author: pmfricke@wisc.edu
mRNA concentrations on d 20 than control heifers. Treatment with hCG did not affect pregnancy loss in experiment 1, whereas heifers treated with hCG at the time of IVF embryo transfer had fewer pregnancy losses from d 32 to 67 than control heifers. We concluded that treatment with 2,000 IU of hCG $7 \mathrm{~d}$ after $\mathrm{AI}$ or at the time of embryo transfer increased $\mathrm{P} 4$ concentrations without affecting $\mathrm{P} / \mathrm{AI}$ or $\mathrm{P} / \mathrm{ET}$ in nulliparous Holstein heifers.

Key words: human chorionic gonadotropin, artificial insemination, embryo transfer, dairy heifer

\section{INTRODUCTION}

Embryo transfer (ET) has become increasingly popular in the US dairy industry since it was first commercialized in the 1970s. According to annual reports from the American Embryo Transfer Association (AETA, 2018), the number of fresh and frozen bovine in vitrofertilized (IVF) embryo transfers increased from 26,742 in 2010 to 117,712 in 2016. Pregnancy loss is a common problem in dairy cattle (Humblot, 2001; Santos et al., 2001) that has substantial economic consequences due to critical delays in time to pregnancy and decreased offspring (Cabrera, 2012), and pregnancy loss after IVF ET is reported to be greater in dairy cows than after AI (Matsuyama et al., 2012).

Progesterone (P4) is a key hormone in the establishment and maintenance of pregnancy in cattle. Embryonic survival is dependent on secretion of interferon-tau (IFNT) during blastocyst elongation (Mann and Lamming, 2001) and inhibits uterine secretion of $\mathrm{PGF}_{2 \alpha}$ pulses, thereby preventing luteolysis. Although the effects of exogenous $\mathrm{P} 4$ treatment are not consistent among studies, supplementation of P4 from 3 to 13 and $16 \mathrm{~d}$ after $\mathrm{AI}$ advanced elongation of the conceptus (Carter et al., 2008), which resulted in earlier secretion of IFNT (Mann et al., 2006) and increased conception rates (Mann and Lamming, 1999). Increasing P4 concentrations in Holstein and Holstein-crossbred heifers by treatment with $\mathrm{GnRH} 5 \mathrm{~d}$ after ovulation did not 
affect pregnancies per ET (P/ET), but decreased pregnancy loss for stage 7 embryos (Garcia-Guerra et al., 2015). By contrast, decreased circulating P4 concentrations after ovulation decreased the expression of genes associated with embryo elongation (Forde et al., 2012) and decreased embryo growth (Carvalho et al., 2017).

One method to increase circulating $\mathrm{P} 4$ concentrations after AI or ET is by treatment with human chorionic gonadotropin (hCG; Price and Webb, 1989; De Rensis et al., 2010). To date, many studies have tested the effect of treatment with hCG after AI on pregnancies per AI (P/AI) or pregnancy loss with mixed results. In cows, treatment with hCG on d 5 (Schmitt et al., 1996; Santos et al., 2001; Nascimento et al., 2013), 7 (Sianangama and Rajamahendran, 1992; Dahlen et al., 2010; Wallace et al., 2011; Torres et al., 2013a), and 14 (Sianangama and Rajamahendran, 1992) increased P4 concentrations; however, effects on pregnancy outcomes and pregnancy loss varied. Pregnancy outcomes for heifers treated with hCG have varied even more; P/ AI increased after treatment with hCG on d 4 (Breuel et al., 1989) and 7 (Chagas e Silva and Lopes da Costa, 2005; Torres et al., 2013b), whereas no difference was reported in other studies when beef heifers were treated with hCG on d 4 (Breuel et al., 1990), 5 (Funston et al., 2005), or 6 (Funston et al., 2005).

The objectives of our study were to assess the effect of treatment with 2,000 IU of hCG $7 \mathrm{~d}$ after AI or at the time of ET on reproductive outcomes, including P4, pregnancy-specific protein B (PSPB), interferonstimulated gene 15 (ISG15), and pregnancy outcomes (P/AI or $\mathrm{P} / \mathrm{ET})$, in nulliparous Holstein heifers. Our hypotheses were that heifers treated with hCG would have (1) increased P4 concentrations, (2) increased expression of ISG15 mRNA, and (3) increased serum PSPB concentrations.

\section{MATERIALS AND METHODS}

All animal handling and experimental procedures were approved by the Animal Care and Use Committee of the College of Agriculture and Life Sciences at the University of Wisconsin-Madison.

\section{Heifers, Housing, and Feeding}

Our study was conducted from May to August of 2017 on a commercial dairy herd located near Casco, Wisconsin, that uses both AI and IVF ET on breeding heifers. The farm milks approximately 2,800 Holstein cows and has approximately 700 breeding-age heifers. Height and weight of individual heifers was recorded at birth, weaning, introduction to pens with freestalls, and during transition to the breeding pen $(0,2,5$, and 12 mo, respectively). Heifers weighing $340 \mathrm{~kg}$ or more were eligible for insemination beginning at 12 mo of age. All records and measurements were entered and stored in an on-farm dairy management software program (Dairy Comp 305; Valley Agricultural Software, Tulare, CA). Heifers were fed once daily a TMR consisting of grass hay, alfalfa and corn silage as forage with trace distillers, salt, and Rumensin (Elanco, Greenfield, IN). Freestalls were bedded with dried manure solids and all heifers had ad libitum access to feed and water throughout the experiment.

\section{Experiment 1: Artificial Insemination}

Nulliparous Holstein heifers $(\mathrm{n}=261)$ were AI after a detected estrus, which was evaluated once daily via removal of tail paint. Heifers not detected in estrus $7 \mathrm{~d}$ after entering the breeding pen were treated with $\mathrm{PGF}_{2 \alpha}$ (526 $\mu \mathrm{g}$ of cloprostenol sodium; Estrumate, Merck Animal Health, Kenilworth, NJ) to induce estrus. Heifers were monitored during the next $2 \mathrm{wk}$ for estrus both visually and by tail chalking (Macmillan et al., 1988) and were inseminated once daily in the morning upon detection of rubbed tail chalk. Heifers not detected in estrus, and, therefore not inseminated, received a second $\mathrm{PGF}_{2 \alpha}$ treatment $14 \mathrm{~d}$ after the first. According to the farm protocol, heifers were inseminated with sex-sorted semen for the first 2 inseminations, whereas conventional semen was used for inseminations 3 to 6 .

At the beginning of the experiment, any heifers eligible for AI based on the farm protocol were stratified by AI number and were randomized to receive no treatment (control; $\mathrm{n}=129$ ) or to receive $2,000 \mathrm{IU}$ of $\mathrm{hCG}$ $(2 \mathrm{~mL}$, Chorulon, Merck Animal Health; $\mathrm{n}=132) 7 \mathrm{~d}$ after AI. Heifers diagnosed not pregnant at the first pregnancy diagnosis after their initial enrollment into the experiment were eligible to be re-enrolled in the experiment and were rerandomized to treatments. The day of estrus was considered to be experimental d 0 (Figure 1A).

\section{Experiment 2: Embryo Transfer}

Nulliparous Holstein heifers $(\mathrm{n}=291)$ were synchronized for ET using a 5-d controlled internal drug release (CIDR) synch protocol (Lima et al., 2013; Figure 1A). Briefly, heifers were treated with $\mathrm{GnRH}(86 \mu \mathrm{g}$ i.m.; Fertagyl; Merck Animal Health) and a CIDR (EaziBreed CIDR; Zoetis, New York, NY); 5 d later, the CIDR was removed. Heifers were treated with $\mathrm{PGF}_{2 \alpha}$ (526 $\mu \mathrm{g}$ of cloprostenol sodium; Estrumate, Merck Animal Health) at the time of CIDR removal and 24 $\mathrm{h}$ later, and treatment with GnRH occurred $48 \mathrm{~h}$ after the second $\mathrm{PGF}_{2 \alpha}$ treatment. The last $\mathrm{GnRH}$ treatment 


\section{Experiment 1:}

\section{Al to estrus}
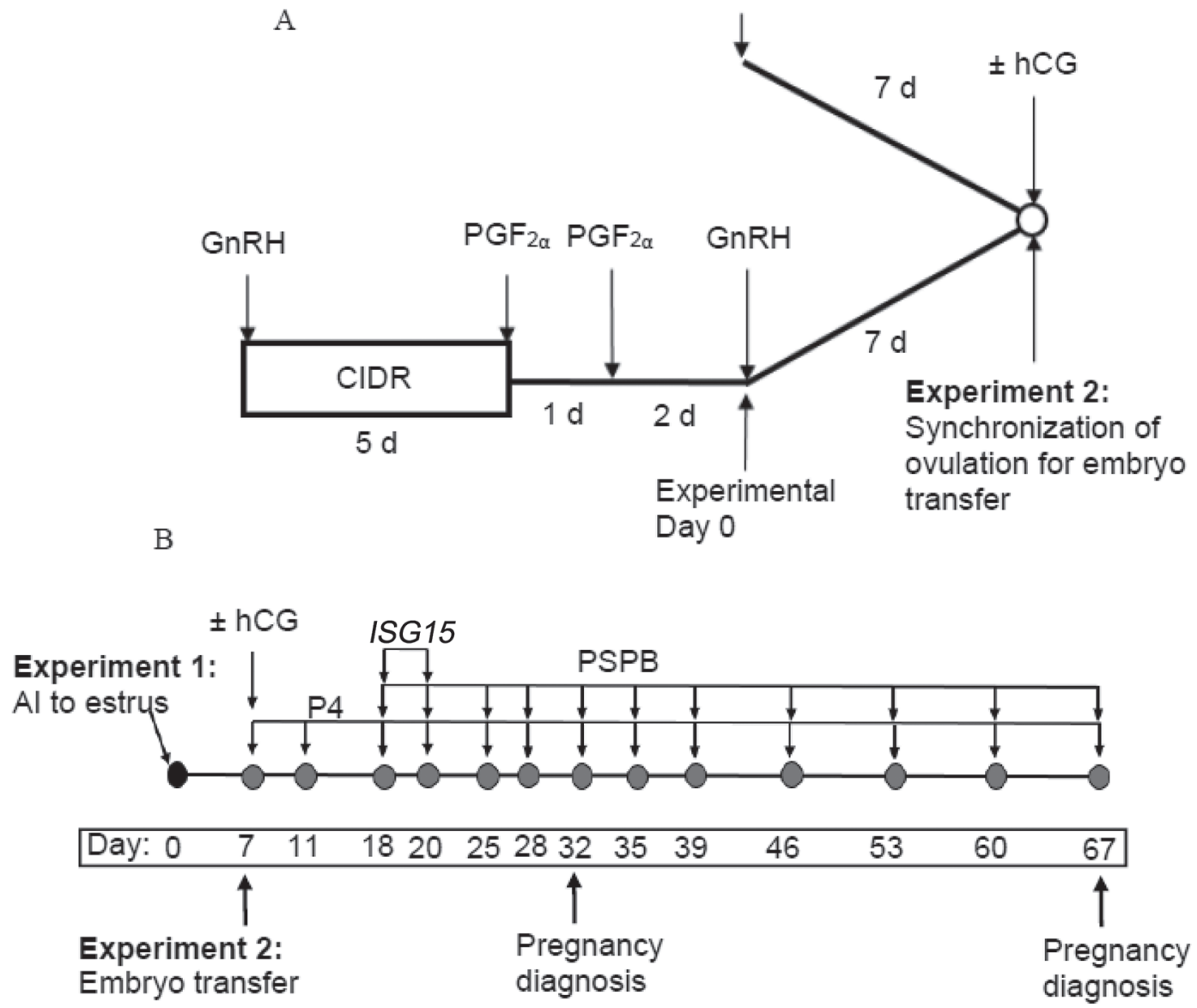

Figure 1. Schematic diagram of the reproductive protocols used in experiments 1 and 2 (A) and a diagram of sampling for experiments 1 and 2 (B). In experiment 1, the day of estrus was considered experimental d 0; in experiment 2, the last GnRH treatment of the 5-d controlled internal drug release (CIDR)-synch protocol was considered experimental d $0 . \mathrm{hCG}=$ human chorionic gonadotropin; $\mathrm{P} 4=$ progesterone; $\mathrm{PSPB}$ = pregnancy-specific protein $\mathrm{B}$.

of the 5-d CIDR synch protocol was considered experimental d 0 (Figure 1A). Grade 1, 2, or 3 IVF embryos were created and graded according to techniques described by the International Embryo Transfer Society (Stringfellow and Givens, 2010). Seven days after the last GnRH treatment of the 5-d CIDR synch protocol, fresh IVF embryos were transferred into heifers that had a palpable corpus luteum as assessed by an experienced veterinarian who conducted all ET throughout the experiment. According to the farm protocol, heifers received up to 3 successive ET.

At the beginning of the experiment, any heifers eligible for ET based on the farm protocol were stratified by $\mathrm{ET}$ number and were randomized to receive no treatment (control; $\mathrm{n}=143$ ) or to receive $2,000 \mathrm{IU}$ of $\mathrm{hCG}$ (2 mL, Chorulon; Merck Animal Health; $\mathrm{n}=148$ ) at the time of ET (i.e., $7 \mathrm{~d}$ after the last $\mathrm{GnRH}$ treatment of the 5-d CIDR-synch protocol). Heifers diagnosed not pregnant at the first pregnancy diagnosis after their initial enrollment into the experiment were eligible to be re-enrolled in the experiment and were rerandomized to treatments. After a nonpregnancy diagnosis, heifers were resynchronized using the same 5-d CIDR synch protocol described for first enrolment.

\section{Pregnancy Diagnosis}

For both experiments, pregnancy was diagnosed on d $32 \pm 3 \mathrm{~d}$ by palpation per rectum, and the pregnancy status of all heifers diagnosed pregnant was reconfirmed by palpation per rectum 35 d later at d $67 \pm 3$.

\section{Blood Sampling}

Blood samples for analysis of P4, PSPB, and ISG15 mRNA expression in blood leukocytes were collected 
from a subgroup of heifers from the initial enrollment into each experiment (experiment 1, $\mathrm{n}=82$ heifers; experiment 2, $\mathrm{n}=104$ heifers). Blood samples for $\mathrm{P} 4$ and PSPB analysis were collected via puncture of the median caudal vein or artery into 8-mL evacuated serum collection tubes (Vacuette, Greiner Bio-One North America Inc., Monroe, NC). Blood samples were collected twice weekly beginning on $\mathrm{d} 7$ and continued until d 32; blood samples from heifers diagnosed pregnant on d 32 were collected weekly until d 67 (Figure 2B). Blood samples were placed on ice immediately upon collection and were centrifuged $\left(1,600 \times g, 4^{\circ} \mathrm{C}\right)$ for 20 min within $2 \mathrm{~h}$ of collection. Serum was harvested and stored at $-20^{\circ} \mathrm{C}$ until assayed for P4 and PSPB concentrations. Blood samples $(3 \mathrm{~mL})$ for analysis of blood leukocyte ISG15 mRNA expression were collected on d 18 and 20 from the coccygeal vessels into Tempus Blood RNA tubes containing $6 \mathrm{~mL}$ of RNA stabilization solution (Applied Biosystems, Foster City, CA). Tempus tubes were shaken vigorously by hand for $20 \mathrm{~s}$
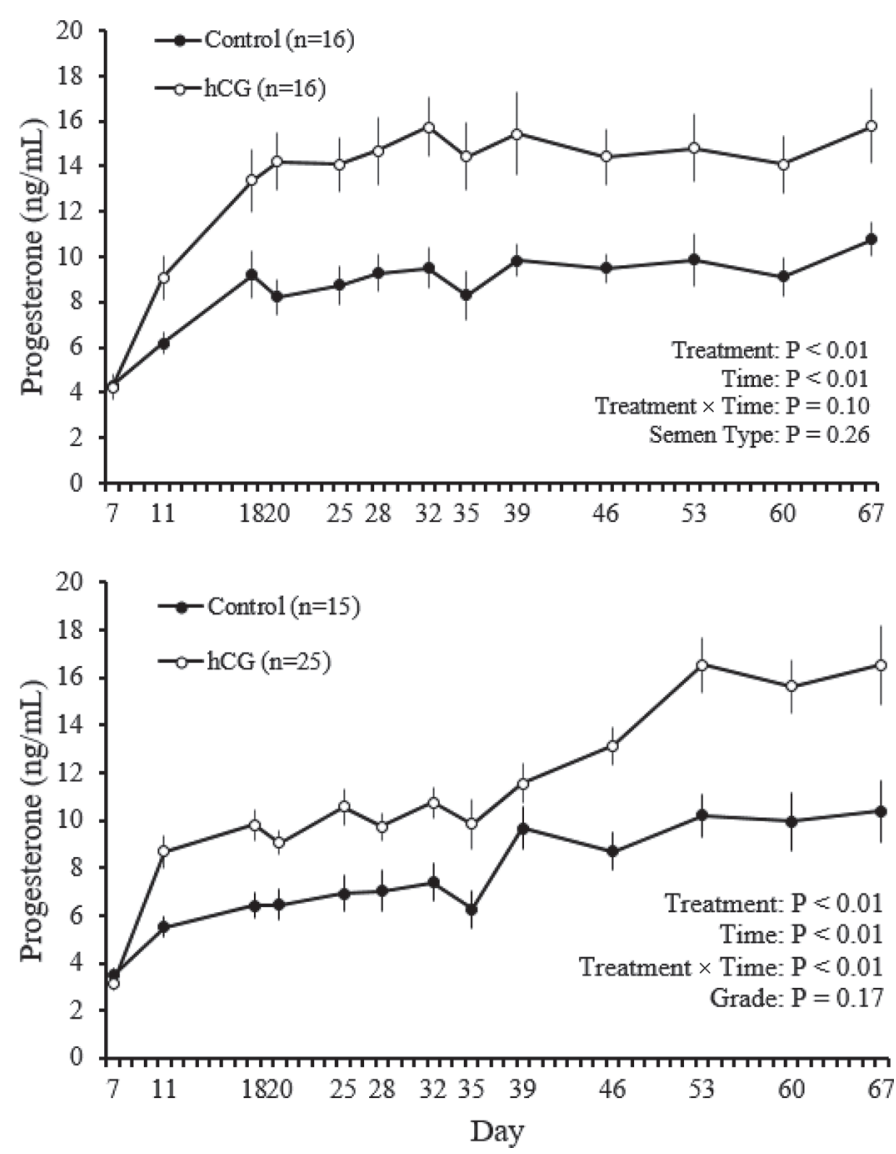

Figure 2. Mean $( \pm \mathrm{SEM})$ serum progesterone concentrations for heifers that maintained pregnancy through $\mathrm{d} 67$ in experiment 1 (upper panel) and experiment 2 (lower panel). $\mathrm{hCG}=$ human chorionic gonadotropin. immediately after blood sample collection, and whole blood was stored in the Tempus tubes at $-20^{\circ} \mathrm{C}$ until the mRNA isolation procedure.

\section{Analysis of P4 and PSPB}

Serum P4 concentrations were determined using a solid-phase, no-extraction RIA (MP Biomedicals, Solon, $\mathrm{OH}$ ). The average sensitivity for the 2 assays was $0.005 \mathrm{ng} / \mathrm{mL}$. The average intra-assay coefficient of variation $(\mathbf{C V})$ was $9.5 \%$ and the interassay $\mathrm{CV}$ was $6.9 \%$ based on a quality control sample $(2.50 \mathrm{ng} / \mathrm{mL}$ of $\mathrm{P} 4$ ) that was replicated within each $\mathrm{P} 4$ assay. Serum PSPB concentrations were determined using a quantitative ELISA (Biopryn, Bio-Tracking LLC, Moscow, ID). The average intra-assay CV for the high- and lowquality control samples was 5 and $6 \%$, respectively, and interassay CV was $5 \%$ for both high- and low-quality control sample based on a quality control sample (0.9 $\mathrm{ng} / \mathrm{mL}$ of PSPB) that was replicated within each PSPB assay.

\section{Analysis of ISG15}

Total RNA was extracted from blood leukocytes using the Tempus Spin RNA Isolation Kit (Applied Biosystems) as per the manufacturer's instructions (http://tools.thermofisher.com/content/sfs/manuals/ 4382075b.pdf), including the optional DNase step. Extracted RNA $(1 \mu \mathrm{g})$ was reverse transcribed to cDNA (Bio-Rad iScript Reverse Transcription Supermix \#1708840; Bio-Rad, Hercules, CA). Quantitative real-time PCR was conducted with the CFX96 Touch Real-Time PCR Detection System (Bio-Rad). Reaction mixtures and cycling conditions were performed as described elsewhere (Carvalho et al., 2017). Amplification efficiencies of primers were accepted within a range of 95 to $105 \%$ efficiency, and primer specificity was assessed by the presence of a single temperature dissociation peak. Cyclophilin A (NM_178320; forward 5'-CACCGTGTTCTTCGACATCG-3', reverse 5'-ACAGCTCAAAAGAGACGCGG-3') was used as a housekeeping gene, and all samples were analyzed for ISG15 (NM_174366; forward 5'-GGTATGAGCTGAAGCAGTT-3', reverse 5'-ACCTCCCTGCTGTCAAGGT- $\left.3^{\prime}\right)$. Analysis was conducted using the $2^{-\Delta \Delta \mathrm{Ct}}$ method (Livak and Schmittgen, 2001).

\section{Statistical Analyses}

All statistical analyses were performed using SAS computational software version 9.4 for Microsoft Windows (SAS Institute Inc., Cary, NC). Analyses of binary response data (P/AI, P/ET, and pregnancy loss) were 
Table 1. Effect of treatment on mean $( \pm \mathrm{SEM})$ progesterone $(\mathrm{ng} / \mathrm{mL})$ concentrations in heifers that maintained pregnancy in experiment $1^{1}$

\begin{tabular}{|c|c|c|c|c|c|}
\hline Day & $\begin{array}{c}\text { Control } \\
(\mathrm{n}=16)\end{array}$ & $\begin{array}{c}\mathrm{hCG} \\
(\mathrm{n}=16)\end{array}$ & Difference & $\begin{array}{c}\text { Increase } \\
(\%)\end{array}$ & $P$-value \\
\hline 7 & $4.3 \pm 0.3$ & $4.2 \pm 0.6$ & -0.1 & - & 0.92 \\
\hline 11 & $6.2 \pm 0.5$ & $9.1 \pm 0.9$ & +2.9 & 47 & $<0.01$ \\
\hline 18 to 67 & $9.2 \pm 0.3$ & $14.7 \pm 0.4$ & +5.4 & 59 & $<0.01$ \\
\hline
\end{tabular}

${ }^{1}$ Seven days after AI, heifers were randomly assigned to receive no treatment (control) or 2,000 IU of human chorionic gonadotropin (hCG).

performed by logistic regression using the GLIMMIX procedure of SAS. Selection of the model that best fit the data for each variable of interest was performed by finding the model with the lowest value for the Akaike information criterion using a backward elimination procedure that removed all variables with $P>0.10$ from the model. The fixed effect of treatment was forced to remain in each model. The initial model for experiment 1 included the fixed effects of semen type (sex-sorted vs. conventional), treatment, AI number, and the 2-way interactions; the final model included the fixed effects of semen type and treatment. The initial model for experiment 2 included the fixed effects of embryo stage (stage $4,5,6,7$, and 8), grade (grade 1, 2, or 3), ET number, treatment, and the 2 -way interactions; the final model included the fixed effects of embryo grade and treatment. Heifer was the experimental unit and each AI or ET was considered to be an independent event.

Concentrations of P4 and PSPB were analyzed by ANOVA using the MIXED procedure of SAS. The model contained the fixed effects of treatment, time, and the 2-way interaction. Due to repeated measures within each heifer, a repeated statement was used to account for autocorrelations by modeling the spatial power between sequential measurements. Concentrations of ISG15 mRNA on d 18 and 20 were analyzed by ANOVA using the MIXED procedure of SAS. The model contained the fixed effects of treatment, pregnancy status, and time after the stepwise elimination of nonsignificant interactions. Data from the ISG15 mRNA analysis were further analyzed by generating receiver operating characteristic (ROC) curves using the LOGISTIC procedure in SAS to determine a cutoff threshold for a positive ISG15 mRNA expression indicative of pregnancy. Only nonpregnant heifers with a normal luteal phase of $18 \mathrm{~d}$ (i.e., true nonpregnant) and heifers diagnosed pregnant (i.e., true pregnant) were used to generate ROC curves to establish ISG15 mRNA pregnancy cutoffs. The model contained the fixed effect of pregnancy and ISG15 mRNA expression as a variable.

A significant difference between levels of a classification variable was declared when $P \leq 0.05$, whereas differences between $P>0.05$ and $P \leq 0.10$ were declared a statistical tendency. Data are presented as least squares means \pm standard error of the means obtained from the MIXED procedure of SAS.

\section{RESULTS AND DISCUSSION}

\section{Effect of Treatment on Serum P4 Concentrations}

In the present study, heifers treated with hCG that maintained pregnancy through d 67 had greater plasma $\mathrm{P} 4$ concentrations than pregnant control heifers $(P \leq$ 0.01 ) from d 11 to 67 of pregnancy in both experiment 1 (Figure 2, upper panel) and 2 (Figure 2, lower panel). Serum P4 concentrations did not differ between treatments in either experiment on $\mathrm{d} 7$; however, $\mathrm{P} 4$ concentrations were about $1 \mathrm{ng} / \mathrm{mL}$ greater on $\mathrm{d} 7$ in experiment 1 versus $2(4.26$ vs. $3.31 \mathrm{ng} / \mathrm{mL}$; Tables 1 and 2). Treatment with hCG increased $(P<0.01) \mathrm{P} 4$ concentrations on d 11 (47 vs. $58 \%$ increase for experiment 1 vs. 2, respectively) and from d 18 to 67 (59 vs.

Table 2. Effect of treatment on mean $( \pm \mathrm{SEM})$ progesterone $(\mathrm{ng} / \mathrm{mL})$ concentrations in heifers that maintained pregnancy in experiment $2^{1}$

\begin{tabular}{lccccc}
\hline Day & $\begin{array}{c}\text { Control } \\
(\mathrm{n}=15)\end{array}$ & $\begin{array}{c}\mathrm{hCG} \\
(\mathrm{n}=25)\end{array}$ & Difference & $\begin{array}{c}\text { Increase } \\
(\%)\end{array}$ & $P$-value \\
\hline 7 & $3.5 \pm 0.3$ & $3.1 \pm 0.3$ & -0.4 & - & 0.42 \\
11 & $5.5 \pm 0.4$ & $8.7 \pm 0.7$ & +3.2 & 58 & $<0.01$ \\
18 to 67 & $8.1 \pm 0.3$ & $12.2 \pm 0.3$ & +4.1 & 50 & $<0.01$ \\
\hline
\end{tabular}

${ }^{1}$ Heifers were randomly assigned to receive no treatment (control) or 2,000 IU of human chorionic gonadotropin (hCG) at transfer of an IVF embryo $7 \mathrm{~d}$ after the last $\mathrm{GnRH}$ treatment of a 5 -d controlled internal drug release-synch protocol. 
$50 \%$ increase for experiment 1 vs. 2 , respectively) in both experiments (Tables 1 and 2).

Progesterone produced by the corpus luteum plays a critical role in the establishment and maintenance of pregnancy in cattle (Mann and Lamming, 1999). Conception failure and poor embryonic development can result from prolonged low circulating $\mathrm{P} 4$ between 5 and $10 \mathrm{~d}$ after insemination (Mann et al., 1999; Thatcher et al., 2001). The objective of the present experiment was to increase P4 after AI or ET by treatment with hCG. We chose to treat heifers with hCG on $\mathrm{d} 7$ rather than d 5 of the estrous cycle to induce ovulation of a larger follicle, thereby forming a larger corpus luteum that produces more P4 (Vasconcelos et al., 2001). Although we did not assess ovulatory response to hCG or formation of accessory corpus luteum in these experiments, we expected a high ovulatory response to hCG treatment administered on $\mathrm{d} 7$ of the estrous cycle because a first-wave dominant follicle would be present. The homology in $\beta$-subunits between hCG and bovine LH is $\sim 80 \%$ (Pierce and Parsons, 1981); thus, treatment with hCG has an LH-like effect in cattle, resulting in an increase in serum $\mathrm{P} 4$ concentration either by stimulating an increase in $\mathrm{P} 4$ production from the existing corpus luteum (Stevenson et al., 2007), by inducing ovulation of a dominant follicle to form an accessory corpus luteum (Schmitt et al., 1996; Santos et al., 2001; Thatcher et al., 2001; Nascimento et al., 2013), or via both mechanisms. In other experiments, treatment with hCG during the early (d 4 to 7 ) luteal phase when a dominant follicle of the first follicular wave is present caused formation of an accessory corpus luteum in 83 (Price and Webb, 1989), 97 (Torres et al., 2013b), and 100\% (Diaz et al., 1998) of nulliparous Holstein heifers.

\section{Effect of Pregnancy Status on Circulating P4}

Heifers diagnosed pregnant on d 32 in experiment 1 had similar $\mathrm{P} 4$ concentrations to heifers diagnosed not pregnant on $\mathrm{d} 7$ and 11 , but greater $(P<0.01)$ serum $\mathrm{P} 4$ than heifers diagnosed not pregnant beginning on d 18 (Figure 3, upper panel); this difference continued through d $32(13.1 \pm 1.0$ vs. $4.4 \pm 0.9 \mathrm{ng} / \mathrm{mL}$, pregnant vs. open). The decrease in serum P4 on $\mathrm{d} 18$ in heifers diagnosed not pregnant was due to luteolysis (Mann et al., 1999). Differences in P4 due to pregnancy status before luteolysis in the present study are in agreement with others. When heifers were inseminated to a detected estrus, P4 concentrations did not differ between pregnant and nonpregnant cows and heifers $7 \mathrm{~d}$ after AI (Santos et al., 2001; Chagas e Silva and Lopes da Costa, 2005) or ET (Niemann et al., 1985; Stubbings and Walton, 1986; Chagas e Silva et al., 2002; Chagas e Silva and Lopes da Costa, 2005; Torres et al., 2013b).
In contrast to experiment 1 , heifers diagnosed pregnant at $\mathrm{d} 32$ in experiment 2 had greater $(P<0.01)$ serum $\mathrm{P} 4$ at ET (i.e., $7 \mathrm{~d}$ after the second $\mathrm{GnRH}$ treatment) than heifers diagnosed not pregnant (Figure 3, lower panel). The difference in pregnancy outcomes based on P4 concentrations on the day of ET adds to this often reported yet poorly understood observation (Dahlen et al., 2010; Pereira et al., 2013). Dahlen et al. (2010) reported that pregnant beef cows had greater P4 concentrations than nonpregnant cows $7 \mathrm{~d}$ after fixedtime AI after a Co-Synch + CIDR protocol (Larson et al., 2006). In addition, Pereira et al. (2013) reported that lactating dairy cows with $\mathrm{P} 4<1.55 \mathrm{ng} / \mathrm{mL}$ on the day of ET were more likely to undergo pregnancy loss from 28 to $60 \mathrm{~d}$. In the present study, we noted a tendency $(P=0.06)$ for $\mathrm{P} 4$ concentrations to be greater in heifers that maintained pregnancy until d 67 than in heifers that underwent pregnancy loss from d 32 to 67 (data not shown). By contrast, Pereira et al. (2016) reported $\mathrm{P} 4$ concentrations on $\mathrm{d} 7$ were associated with $\mathrm{P} / \mathrm{AI}$ but not $\mathrm{P} / \mathrm{ET}$ in lactating dairy cows. In addition, Stubbings and Walton (1986) reported that P4 concentrations at ET were not related to pregnancy

\section{口Nonpregnant $\quad$ Pregnant}
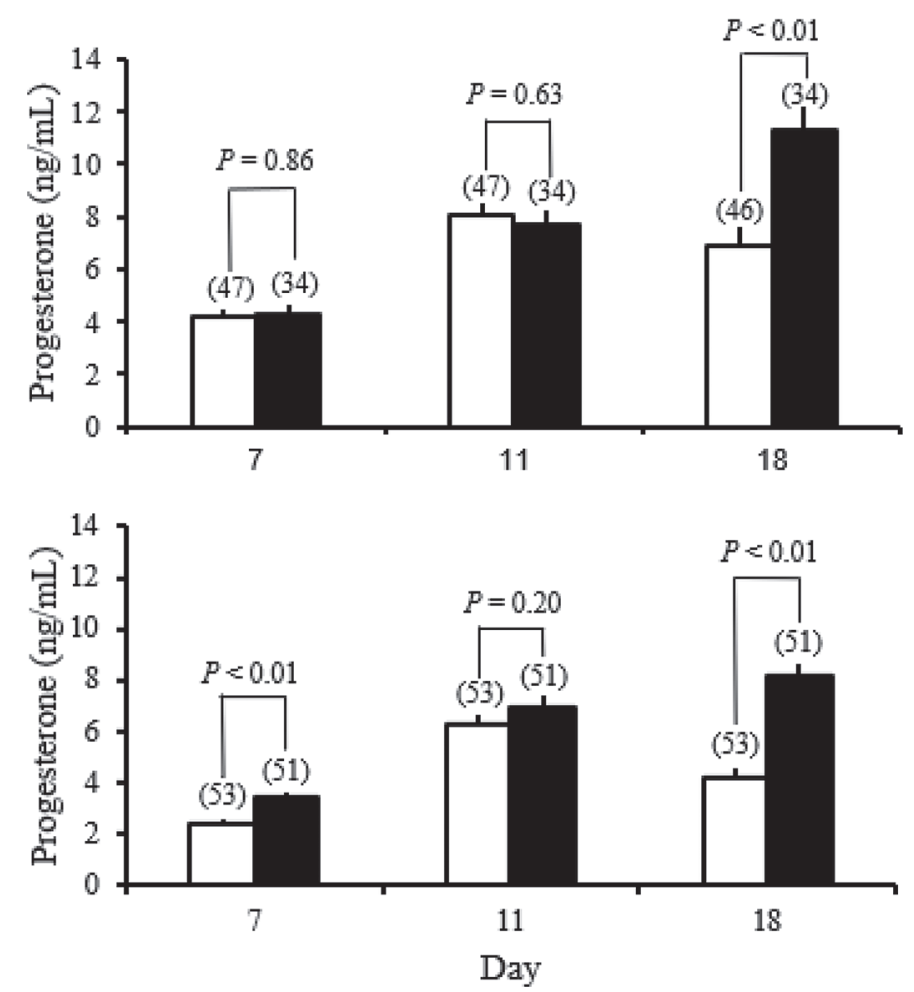

Figure 3. Effect of pregnancy status at d 32 on mean $( \pm$ SEM $)$ serum progesterone concentrations on $\mathrm{d} 7,11$, and 18 in experiment 1 (upper panel) and experiment 2 (lower panel). 
status in Holstein-Friesian heifers; however, pregnancy status was not assessed until $60 \mathrm{~d}$ in that study.

Overall, it is possible that the observed difference in pregnancy outcomes was due to ovulation of a smaller follicle in heifers submitted to a 5-d CIDR synch protocol. Ovulation of a smaller follicle results in a smaller corpus luteum that secretes less P4 after AI in lactating dairy cows (Vasconcelos et al., 2001). This idea agrees with the lower initial P4 concentrations of heifers that were synchronized or resynchronized using a 5-d CIDR synch protocol for ET in experiment 2 than of heifers inseminated to a detected estrus in experiment 1 in the present study (Tables 1 and 2). Further research is needed to understand how and why pregnancy outcomes are related to $\mathrm{P} 4$ concentrations early after the second GnRH treatment for heifers receiving IVF embryos.

\section{Effect of Treatment on Pregnancy Outcomes and Pregnancy Loss}

Of the 261 pregnancy outcomes after AI analyzed in experiment 1, data from $224 \mathrm{AI}(86 \%)$ were from heifers initially enrolled into the experiment, whereas $37 \mathrm{AI}$ $(14 \%)$ were from heifers diagnosed not pregnant after first enrolment that were subsequently rerandomized to treatments and enrolled into experiment 1 a second time. Mean $( \pm$ SEM) AI number for heifers initially enrolled into experiment 1 was $1.98 \pm 0.09$ (range $=1$ to $6)$, and mean $( \pm \mathrm{SEM}) \mathrm{AI}$ number for heifers re-enrolled into experiment 1 was $2.95 \pm 0.19$ (range $=2$ to 6 ). Of the 291 pregnancy outcomes after ET analyzed in experiment 2, data from $249 \mathrm{ET}(86 \%)$ were from heifers initially enrolled into the experiment, whereas 42 ET $(14 \%)$ were from heifers diagnosed not pregnant after first enrolment that were subsequently rerandomized to treatments and enrolled into experiment 2 a second time. Mean ( \pm SEM) ET number for heifers initially enrolled into experiment 2 was $1.37 \pm 0.04$ (range $=$ 1 to 3 ), and mean ( \pm SEM) ET number for heifers re-enrolled into experiment 2 was $2.33 \pm 0.07$ (range
$=2$ to 3 ). Neither AI number (experiment 1 ) nor ET number (experiment 2) differed between treatments or affected pregnancy outcomes or pregnancy loss.

Overall, $\mathrm{P} / \mathrm{AI}$ and $\mathrm{P} / \mathrm{ET}$ did not differ between treatments for heifers in both experiment 1 (Table 3 ) and experiment 2 (Table 4 ) at either d 32 or 67 . We did note, however, an effect of semen type on P/AI in experiment 1 (Table 3 ). Experiment 1 was not designed to directly test the effect of semen type on fertility because semen type was confounded with insemination number. Nonetheless, P/AI in experiment 1 was affected by semen type, in which $\mathrm{P} / \mathrm{AI}$ to sex-sorted semen was $55 \%$ that of heifers inseminated using conventional semen (Table 3). The observed difference in fertility of heifers inseminated using sex-sorted versus conventional semen in the present study was greater than the 70 to $85 \%$ of the fertility of conventional semen reported by others (Bodmer et al., 2005; DeJarnette et al., 2009; Chebel et al., 2010; Seidel, 2014). Decreased fertility of heifers inseminated with sex-sorted semen can be explained in part by the difference in the number of sperm per straw $\left(2.1 \times 10^{6}\right.$ vs. $15-20 \times 10^{6}$ sperm, sexed vs. conventional) and damage to sperm that occurs during the sorting process. Furthermore, timing of insemination relative to ovulation in experiment 1 was not optimized because detection of estrus was performed once daily based on rubbed tail chalk. The optimal timing of AI relative to ovulation may differ for sex-sorted semen due to the decreased lifespan of sperm in the female reproductive tract resulting from the sorting process (Sá Filho et al., 2010; Gosálvez et al., 2011; Sales et al., 2011). More P/ AI occurred when insemination with sex-sorted semen occurred 60 versus $54 \mathrm{~h}$ after CIDR removal (Sales et al., 2011) as well as 16.1 to 24 (Sá Filho et al., 2010) and 13 to $41 \mathrm{~h}$ (Bombardelli et al., 2016) after the onset of estrus. By contrast, inseminating dairy heifers with conventional semen immediately after a detected estrus resulted in similar conception rates compared with strict use of the am-pm rule (Wahome et al., 1985). The effect of treatment on $\mathrm{P} / \mathrm{AI}$ and $\mathrm{P} / \mathrm{ET}$ (Tables 3 and 4) should be interpreted with caution because of

Table 3. Effect of treatment and semen type [\% (no./no.)] on pregnancies per artificial insemination $(\mathrm{P} / \mathrm{AI})$ and pregnancy loss for Holstein heifers in experiment 1

\begin{tabular}{|c|c|c|c|c|c|c|}
\hline \multirow[b]{2}{*}{ Day } & \multicolumn{2}{|c|}{ Treatment $^{1}$} & \multicolumn{2}{|c|}{ Semen type ${ }^{2}$} & \multicolumn{2}{|c|}{$P$-value } \\
\hline & Control & $\mathrm{hCG}$ & $\mathrm{CS}$ & SX & Treatment & Semen \\
\hline 32 & $41(53 / 129)$ & $43(57 / 132)$ & $62(46 / 74)$ & $34(64 / 187)$ & 0.96 & $<0.01$ \\
\hline 67 & $41(53 / 129)$ & $41(54 / 132)$ & $61(45 / 74)$ & $33(62 / 187)$ & 0.66 & $<0.01$ \\
\hline $\operatorname{Loss}^{3}$ & $0(0 / 53)$ & $5(3 / 57)$ & $2(1 / 46)$ & $3(2 / 64)$ & 0.97 & 0.62 \\
\hline
\end{tabular}

${ }^{1}$ Seven days after AI, heifers were randomly assigned to receive no treatment (control) or 2,000 IU of human chorionic gonadotropin ( $\mathrm{hCG}$ ).

${ }^{2} \mathrm{CS}=$ heifers inseminated with conventional semen; SX = heifers inseminated with sex-sorted semen.

${ }^{3}$ Heifers diagnosed pregnant $32 \mathrm{~d}$ after AI that were diagnosed not pregnant $67 \mathrm{~d}$ after AI. 
the limited number of heifers per treatment enrolled into each experiments.

Overall, hCG treatment did not affect pregnancy outcomes $(\mathrm{P} / \mathrm{AI}$ or $\mathrm{P} / \mathrm{ET})$ at d 32 or 67 for heifers in both experiments. Effects of hCG treatment $7 \mathrm{~d}$ after AI on fertility have varied among studies. No difference in $\mathrm{P} / \mathrm{AI}$ was observed in beef heifers when treated with hCG $4 \mathrm{~d}$ after AI (Breuel et al., 1990), and at 2 out of 3 locations 5 and $6 \mathrm{~d}$ after AI (Funston et al., 2005) or 7 d after AI (Chagas e Silva and Lopes da Costa, 2005) in dairy heifers. An effect of parity on fertility has been reported in lactating dairy cows in which treatment with hCG $5 \mathrm{~d}$ after TAI increased fertility in primiparous cows but did not increase fertility in multiparous cows (Nascimento et al., 2013). Considering that treatment with hCG has been reported to affect fertility based on parity, it is possible that the high fertility observed in nulliparous heifers raised under optimal conditions in the present study may not benefit from treatment with hCG.

In experiment 1 , treatment with hCG did not affect pregnancy loss from d 32 to 67 when heifers were inseminated to a detected estrus (Table 3 ). An interesting observation in experiment 2 was the effect of treatment on pregnancy loss from d 32 to $67(P=0.04)$, in which heifers treated with hCG had fewer pregnancy losses than control heifers (Table 4). This observation should be interpreted with caution because this experiment was not statistically powered to assess pregnancy loss. None of the heifers diagnosed pregnant after AI in experiment 1 lost pregnancies from d 67 to calving, whereas 5 heifers in experiment 2 diagnosed pregnant after IVF ET lost pregnancies from d 67 to calving (3 control heifers and 2 hCG heifers).

Although studies evaluating the effect of hCG on pregnancy loss for heifers receiving ET are limited, treatment with GnRH 5.5 d after ovulation decreased pregnancy loss in stage 7 embryos for Holstein and Holstein-cross Heifers (Garcia-Guerra et al., 2015). Chagas e Silva and Lopes da Costa (2005) reported no effect of hCG treatment on $\mathrm{d} 7$ on $\mathrm{P} / \mathrm{ET}$ in dairy heifers; however, pregnancy loss was not reported in that study. In addition, treatment with hCG $5 \mathrm{~d}$ after ovulation did not affect $\mathrm{P} / \mathrm{ET}$ for lactating Holstein cows receiving ET $7 \mathrm{~d}$ after induction of ovulation (Galvão et al., 2006). In mature beef cows, treatment with hCG at ET $7 \mathrm{~d}$ after ovulation increased P/ET, but no difference was noted in pregnancy loss (Wallace et al., 2011). Similarly, treatment of Black Japanese cows with hCG $6 \mathrm{~d}$ after induction of ovulation increased $\mathrm{P} / \mathrm{ET}$ versus treatment with hCG $1 \mathrm{~d}$ after ovulation and in nontreated controls (Nishigai et al., 2002). Further experiments are needed to support or refute our observation that treatment with 2,000 IU of hCG at the time of ET decreases pregnancy loss.

Developmental stage of transferred embryos did not affect $\mathrm{P} / \mathrm{ET}$ in the present study (data not shown); however, P/AI and pregnancy loss was affected by embryo grade, in which grade 1 embryos resulted in more $\mathrm{P} / \mathrm{ET}$ than transfer of grade 2 or grade 3 embryos (Table 4 ). In addition, heifers receiving grade 1 embryos tended $(P=0.09)$ to have fewer pregnancy losses than heifers receiving grade 3 embryos (Table 4). Embryos are graded by evaluating stage of development and detectable defects. The decrease in $\mathrm{P} / \mathrm{ET}$ with increasing embryo grade has been consistently reported by others (Hasler, 2001; Chebel et al., 2008).

\section{Effect of Treatment on Serum PSPB Concentrations}

Pregnancy-specific protein B concentrations have been used as an indicator of pregnancy (Sasser et al., 1986) and pregnancy loss (Giordano et al., 2012). Experimentally decreasing serum P4 after AI in lactating dairy cows decreased PSPB concentrations by decreasing embryonic growth (Carvalho et al., 2017), whereas increasing serum P4 can advance embryonic growth by increasing endometrial gene expression responsible for histotroph composition (Forde et al., 2009). In the present experiments, we evaluated the effect of increasing $\mathrm{P} 4$ after AI or ET on trophoblast growth based on serum PSPB concentrations. Figure 4 shows the effect

Table 4. Effect of treatment and embryo grade [\% (no./no.)] on pregnancies per embryo transfer (P/ET) and pregnancy loss for Holstein heifers in experiment 2

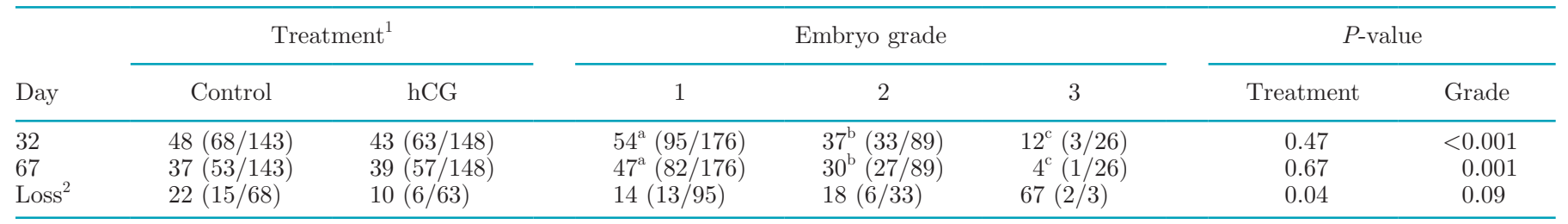

\footnotetext{
${ }^{\mathrm{a}-\mathrm{c}}$ Within a row, percentages with different superscripts differ $(P<0.05)$.

${ }^{1}$ Seven days after the second GnRH treatment, heifers were randomly assigned to receive 2,000 IU of human chorionic gonadotropin (hCG) or remain untreated (control).

${ }^{2}$ Heifers diagnosed pregnant $32 \mathrm{~d}$ after ovulation that were diagnosed not pregnant $67 \mathrm{~d}$ after ovulation.
} 

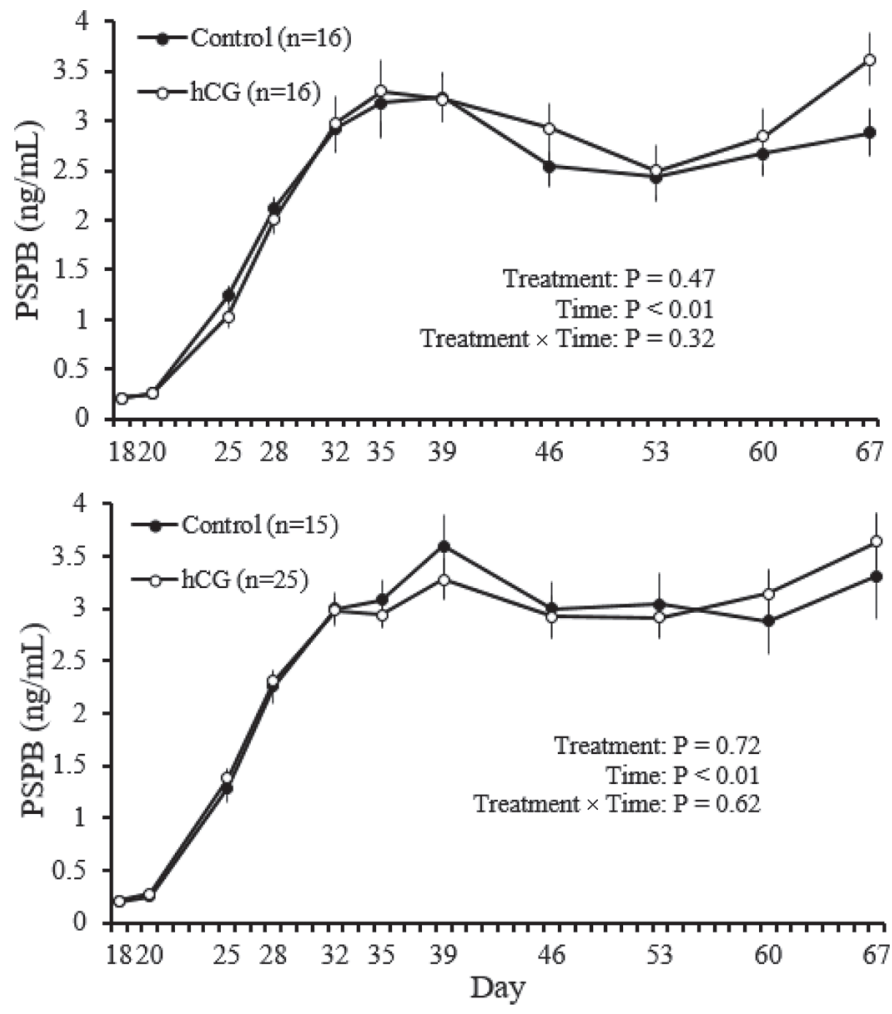

Figure 4. Mean $( \pm \mathrm{SEM})$ serum pregnancy-specific protein $B$ (PSPB) concentrations in heifers that maintained pregnancy through d 67 in experiment 1 (upper panel) and experiment 2 (lower panel). $\mathrm{hCG}=$ human chorionic gonadotropin .

of treatment on serum PSPB profiles for heifers that maintained pregnancy until d 67 in experiment 1 (Figure 4: upper panel) and experiment 2 (Figure 4: lower panel). In both experiments, serum PSPB concentrations in heifers were low on d 18 and 20 then increased until they peaked on d 35 in experiment 1 or d 39 in experiment 2. Overall, treatment did not affect serum PSPB concentrations for pregnant heifers in either experiment, nor was a treatment by time interaction detected.

The lack of an effect of treatment on PSPB concentrations in the present studies suggests that $\mathrm{P} 4$ concentrations were not limiting trophoblast growth in heifers that maintained pregnancy after AI or ET until d 67. Exogenous supplementation of P4 from 7 to $19 \mathrm{~d}$ after ET increased PSPB concentrations for heifers receiving demi-embryos beginning $25 \mathrm{~d}$ after estrus, whereas heifers receiving whole embryos had a less pronounced PSPB increase from 49 to $63 \mathrm{~d}$ (Lopes-da-Costa et al., 2011). Thus, smaller and less viable embryos may benefit from increased P4 early after transfer to compensate for their smaller initial size. Temporarily decreasing P4 after timed AI in lactating dairy cows decreased PSPB concentrations through the first $67 \mathrm{~d}$ of pregnancy and embryonic growth (Carvalho et al., 2017). Data from the present study suggest that the opposite is not necessarily true in nulliparous Holstein heifers. In heifers, PSPB has a higher sensitivity for a positive pregnancy status on d 24 and 26 of pregnancy than in cows (Humblot et al., 1988). Increasing $\mathrm{P} 4$ by treatment with $\mathrm{hCG}$ in the present study had no effect on PSPB concentrations; this can partially explain why hCG does not appear to benefit highly fertile animals (Santos et al., 2001), or it may indicate that $\mathrm{P} 4$ is not the rate-limiting factor for embryonic development in heifers once $\mathrm{P} 4$ reaches adequate concentrations in circulation.

\section{Effect of Treatment on ISG15 mRNA Expression}

The bovine blastocyst initiates the production and release of a paracrine signal, IFN $\tau$, to prevent secretion of uterine $\mathrm{PGF}_{2 \alpha}$ pulses, thereby preventing luteolysis and initiating maternal recognition of pregnancy (Spencer and Bazer, 2004). Produced by the conceptus, IFN $\tau$ is detectable in $\mathrm{d} 7$ bovine blastocysts (Farin et al., 1990; Kubisch et al., 1998) and is dramatically upregulated concomitant to blastocyst elongation (Mann and Lamming, 1999; Mann and Lamming, 2001; Rizos et al., 2012) due to its role in the regulation of genes that play pivotal roles in implantation and conceptus growth (Spencer et al., 2007). The presence of IFN $\tau$ can be detected indirectly through upregulation of several IFN-induced genes, including ISG15 (Han et al., 2006). Finally, an experiment directly comparing gene expression by in vivo- and in vitro-produced $\mathrm{d} 7$ and 16 embryos reported that the in vitro production of bovine embryos negatively affected the amount of gene expression on $\mathrm{d} 7$ and the rate of development on $\mathrm{d} 16$ (Bertolini et al., 2002). Thus, reproductive outcomes may differ based on embryo type.

Figure 5 illustrates the effect of treatment and pregnancy outcome on relative expression of ISG15 mRNA for heifers in experiment 1 (Figure 5, upper panel) and experiment 2 (Figure 5, lower panel). As expected, we observed an effect of pregnancy status $(P<0.01)$ on ISG15 mRNA expression for heifers in both experiments, in which pregnant heifers had greater ISG15 mRNA expression than nonpregnant heifers. In experiment 1, we found no effect of treatment or time after treatment with hCG on d 7. Interestingly, high relative ISG15 mRNA expression was detected in 1 heifer that underwent pregnancy loss between d 32 and 67 on both d 18 and 20 (13.9 and 9.8, respectively), and we speculated that loss of this pregnancy may have been due to twins (data not shown). In experiment 2, we observed no effect of treatment with hCG at the time of ET on ISG15 mRNA expression; however, we did detect an effect of day in which $I S G 15 \mathrm{mRNA}$ expression increased 
$(P<0.01)$ in heifers from d 18 to 20 . In addition, there was no treatment by pregnancy status interaction on relative ISG15 mRNA expression.

\section{Nonpregnant Heifers}

Because heifers in experiment 2 treated with $\mathrm{hCG}$ at the time of ET had fewer pregnancy losses from d 32 to 67 , we sought to further analyze potential effects of hCG treatment earlier after ET in heifers diagnosed not pregnant on d 32. Further, treatment of heifers with hCG at the time of ET may have altered follicular dynamics later during the estrous cycle. The second follicular wave of an estrous cycle begins earlier in nulliparous heifers than in lactating dairy cows (Ginther et al., 1989; Sartori et al., 2004). Treatment with hCG on $\mathrm{d} 7$ induces ovulation of the first wave dominant follicle in a high proportion of heifers (Schmitt et al., 1996), thereby delaying luteolysis by altering follicular dynamics near the time of luteolysis. Heifers with 3 follicular waves tend to have longer interovulatory intervals than heifers with 2 follicular waves (Ginther et al.,

\section{口Control - Nonpregnant DControl - Pregnant \\ QhCG - Nonpregnant DCG - Pregnant}
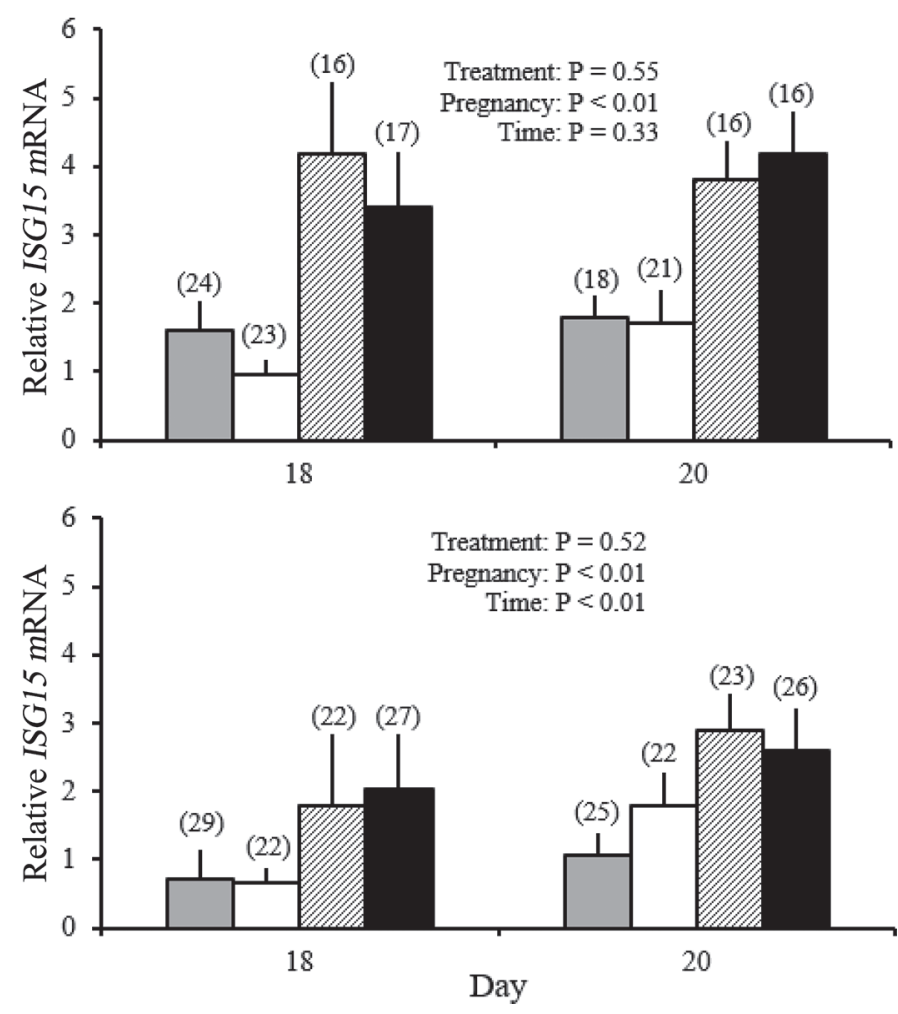

Figure 5. Effect of treatment and pregnancy status on d 32 on mean ( \pm SEM) relative $I S G 15 \mathrm{mRNA}$ on d 18 and 20 in experiment 1 (upper panel) and experiment 2 (lower panel). $\mathrm{hCG}=$ human chorionic gonadotropin.
1989) due to the role of estradiol in luteolysis in which the timing of estradiol secretion regulates the timing of the increased expression of uterine oxytocin receptors and subsequent uterine $\mathrm{PGF}_{2 \alpha}$ secretion (Araujo et al., 2009).

The day of luteolysis was determined for individual heifers in experiments 1 and 2 diagnosed not pregnant and was defined as the day $\mathrm{P} 4$ concentration decreased to $<1.0 \mathrm{ng} / \mathrm{mL}$, as described elsewhere (Ricci et al., 2017). In experiment 1 , only $10 \%$ of hCG-treated versus $50 \%$ of control heifers underwent luteolysis on d 18 (i.e., normal luteal phase; Figure 6, upper panel), whereas $40 \%$ of hCG-treated versus $15 \%$ of control heifers underwent luteolysis on d 25 (i.e., increased luteal phase). Thus, treatment of heifers with hCG in experiment 1 increased the interovulatory interval, likely by inducing ovulation of the first wave dominant follicle, thereby increasing the occurrence of 3-wave estrous cycles.

By contrast, more variability in the timing of luteolysis for heifers after treatment with hCG was observed in experiment 2 (Figure 6, lower panel). Similar to experiment 1 , we noted a tendency $(P<0.09)$ for more control heifers to undergo luteolysis on d 18 (48 vs. $20 \%$, respectively). In contrast to experiment 1 , a

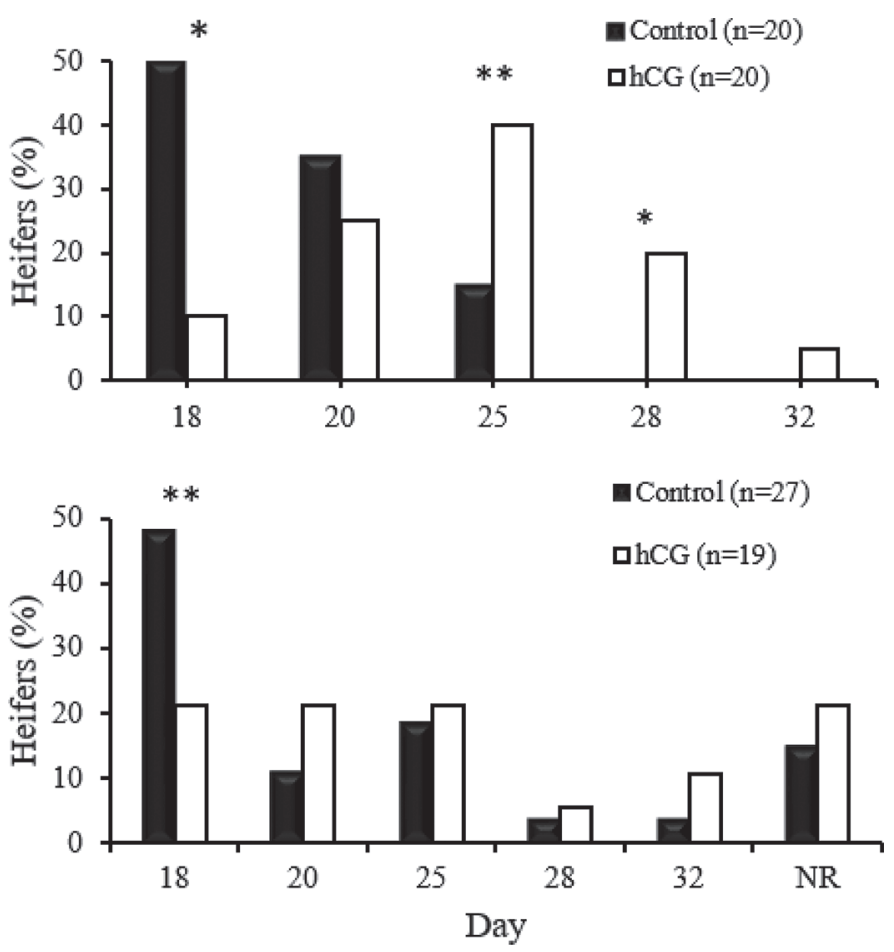

Figure 6. Day of luteolysis (progesterone $<1.0 \mathrm{ng} / \mathrm{mL}$ ) for heifers diagnosed not pregnant on d 32 in experiment 1 (upper panel) and experiment 2 (lower panel). $\mathrm{hCG}=$ human chorionic gonadotropin; $\mathrm{NR}=$ no regression. ${ }^{*}$ Indicates a treatment difference within a day $(P<0.01)$; **indicates a tendency for a treatment difference within a day $(0.05 \leq P<0.09)$. 
subgroup of control heifers $[14.8 \%(4 / 27)]$ and heifers treated with hCG $[21.1 \%$ (4/19)] failed to undergo luteolysis (i.e., $\mathrm{P} 4$ never decreased to $<1 \mathrm{ng} / \mathrm{mL}$ during the sampling period) even though these heifers were diagnosed not pregnant on $d$ 32. This observation supports the idea that although IVF embryos are capable of signaling maternal recognition of pregnancy, as evidenced by extending luteal phases, some of the IVF embryos in the present study did not survive until the pregnancy diagnosis on $\mathrm{d} 32$. Indeed, treatment with hCG at the time of ET in experiment 2 did not affect $\mathrm{P} / \mathrm{ET}$ on $\mathrm{d} 32$. Our results agree with other studies in which lactating dairy cows receiving IVF embryos had high P4 $21 \mathrm{~d}$ after ET but lower P/ET at a pregnancy diagnosis conducted later (Ambrose et al., 1999; Block and Hansen, 2007).

Nonpregnant heifers in both experiments were further grouped by luteal phase duration ( $\leq 20$ vs. $\geq 25 \mathrm{~d}$ ), and heifers diagnosed pregnant on d 32 were grouped by whether they lost or maintained pregnancy from d 32 to 67 to analyze the effect of hCG treatment on mean relative ISG15 mRNA expression on d 20 in heifers from experiment 1 (Figure 7, upper panel) and experiment 2 (Figure 7 , lower panel). In experiment 1, relative ISG15 mRNA expression did not differ between heifers with normal $(\leq 20 \mathrm{~d})$ or extended $(\geq 25 \mathrm{~d})$ luteal phases, suggesting that extended luteal phases in experiment 1 were not due to the presence of IFN $\tau$ secretion from elongated embryos. To further analyze these data, ROC curves were generated to establish the ISG15 cutoff level predictive of pregnancy in both experiments. The effect of treatment on the proportion of nonpregnant heifers and pregnant heifers with ISG15 mRNA concentrations above the pregnancy cutoff threshold are shown in Tables 5 and 6 .

Heifers in experiment 2 with normal luteal phases did not have increased ISG15 mRNA expression. Approximately 20 to $50 \%$ of pregnancy loss in highproducing dairy cows occurs during the first week of
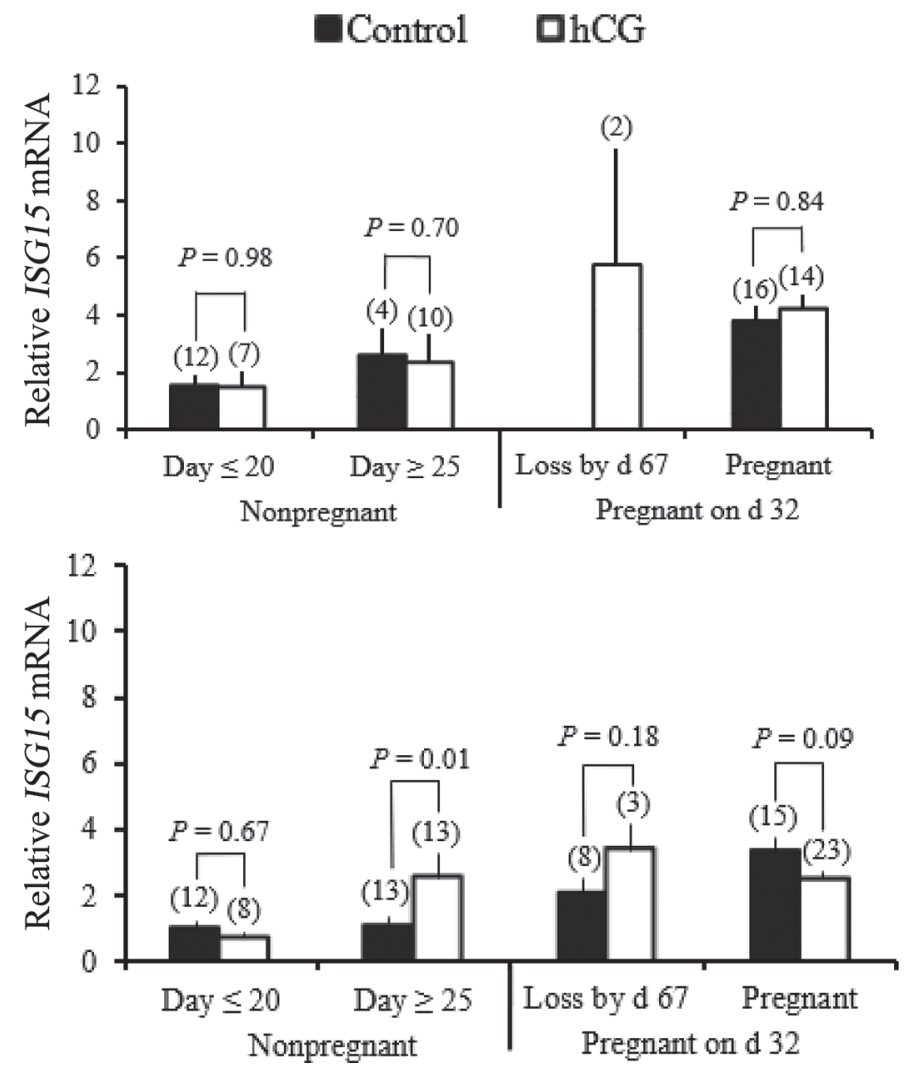

Figure 7. Mean $( \pm \mathrm{SEM})$ relative $I S G 15$ mRNA expression on $\mathrm{d}$ 20 in experiment 1 (upper panel) and experiment 2 (lower panel). Nonpregnant heifers were grouped by luteal phase duration $(\mathrm{d}<20$ vs. $d \geq 25$ ), whereas heifers diagnosed pregnant on $d 32$ were grouped based on whether they underwent pregnancy loss (loss by d 67) or maintained pregnancy (pregnant). $\mathrm{hCG}=$ human chorionic gonadotropin.

pregnancy (Wiltbank et al., 2016); thus, we would not expect pregnancy loss before maternal recognition of pregnancy to affect luteal phase duration. By contrast, heifers in experiment 2 with extended luteal phases and treated with hCG had greater $(P=0.01) I S G 15 \mathrm{mRNA}$ expression than control heifers, suggesting that ex-

Table 5. Percentage (no./no) of heifers with positive ISG15 mRNA expression indicative of pregnancy for nonpregnant heifers in experiment 1 with normal ( $\leq 20 \mathrm{~d}$ ) or extended ( 25 to $32 \mathrm{~d}$ ) luteal phase, and heifers diagnosed pregnant on d 32 that underwent pregnancy loss (loss) or maintained pregnancy until d 67 (pregnant) ${ }^{1}$

\begin{tabular}{lccccc}
\hline & \multicolumn{3}{c}{$\mathrm{d} 18$} & & \multicolumn{2}{c}{$\mathrm{d} 20$} \\
\cline { 2 - 3 } \cline { 5 - 6 } Item & Control & hCG & & Control & hCG \\
\hline $\begin{array}{l}\text { Nonpregnant } \\
\quad 20 \mathrm{~d}\end{array}$ & $29(5 / 17)$ & $17(1 / 6)$ & & $27(3 / 11)$ & $20(1 / 5)$ \\
$\quad 25$ to $32 \mathrm{~d}$ & $100(3 / 3)$ & $31(2 / 13)$ & & $67(2 / 3)$ & $31(4 / 13)$ \\
$\begin{array}{l}\text { Pregnant } \\
\quad \text { Loss }\end{array}$ & & $50(1 / 2)$ & & & $50(1 / 2)$ \\
Pregnant & $75(12 / 16)$ & $82(14 / 17)$ & & $94(15 / 16)$ & $88(14 / 16)$ \\
\hline
\end{tabular}

${ }^{1}$ Seven days after AI, heifers were randomly assigned to receive no treatment (control) or 2,000 IU of human chorionic gonadotropin (hCG). 
Table 6. Percentage (no./no.) of heifers with positive ISG15 mRNA expression indicative of pregnancy for nonpregnant heifers in experiment 2 with normal $(\leq 20 \mathrm{~d})$ or extended $(\geq 25 \mathrm{~d})$ luteal phases, and heifers diagnosed pregnant on d 32 that underwent pregnancy loss (loss) or maintained pregnancy until d 67 (pregnant) ${ }^{1}$

\begin{tabular}{|c|c|c|c|c|}
\hline \multirow[b]{2}{*}{ Item } & \multicolumn{2}{|c|}{ d 18} & \multicolumn{2}{|c|}{ d 20} \\
\hline & Control & $\mathrm{hCG}$ & Control & $\mathrm{hCG}$ \\
\hline \multicolumn{5}{|l|}{ Nonpregnant } \\
\hline$\leq 20 \mathrm{~d}$ & $38(6 / 16)$ & $12(1 / 8)$ & $33(4 / 12)$ & $0(0 / 7)$ \\
\hline$\overline{25} \mathrm{~d}-\mathrm{NR}^{2}$ & $64(7 / 11)$ & $30(3 / 10)$ & $55(6 / 11)$ & $64(7 / 11)$ \\
\hline \multicolumn{5}{|l|}{ Pregnant } \\
\hline Loss & $75(6 / 8)$ & $100(3 / 3)$ & $75(6 / 8)$ & $100(3 / 3)$ \\
\hline Pregnant & $72(10 / 14)$ & $83(20 / 24)$ & $100(15 / 15)$ & $96(22 / 23)$ \\
\hline
\end{tabular}

${ }^{1}$ Seven days after the second GnRH treatment, heifers were randomly assigned to receive 2,000 IU of human chorionic gonadotropin (hCG) or remain untreated (control).

${ }^{2} \mathrm{NR}=$ no regression (progesterone $>1.0 \mathrm{ng} / \mathrm{mL}$ ).

tended luteal phases for heifers receiving IVF embryos and treated with hCG may have occurred due to the presence of elongated embryos producing enough IFN $\tau$ to signal maternal recognition of pregnancy. Expression of ISG15 mRNA can be increased by supplementation of intrauterine IFN $\tau$ (Matsuyama et al., 2012) and by increasing $\mathrm{P} 4$ in crossbred beef heifers (Forde et al., 2009), whereas lactating cows in which $\mathrm{P} 4$ was temporarily decreased after AI had decreased ISG15 mRNA expression (Carvalho et al., 2017). Our results are similar to a study by Matsuyama et al. (2012) in which cows with an extended luteal phase after ET had increased relative ISG15 mRNA expression on d 18 . Taken together, these observations suggest that pregnancy is not consistently established even when IFN $\tau$ is secreted by an elongated embryo. One possibility is that the low expression of ISG15 mRNA detected is indicative of insufficient growth and low viability of embryos, which then die after initiating maternal recognition of pregnancy. In addition, the quantity of IFN $\tau$ may have been insufficient to induce endometrial genes needed to support early embryonic growth (Spencer et al., 2007). Nevertheless, both early and late embryonic mortality are the greatest hurdles to overcome to further increase the adoption of IVF ET in the dairy industry. Results from experiment 2 support a role for treatment with hCG at the time of transfer of an IVF embryo to increase $\mathrm{P} 4$ and possibly to decrease pregnancy loss in nulliparous Holstein heifers. Larger studies are needed to corroborate the observation from the present study that treatment with $2,000 \mathrm{IU}$ of hCG at the time of IVF ET decreases pregnancy loss in nulliparous Holstein heifers.

\section{ACKNOWLEDGMENTS}

We thank Dairy Dreams LLC in Casco, Wisconsin, for their collaboration and assistance with data collection and heifer handling throughout the course of this experiment. This work was supported by the USDA National Institute of Food and Agriculture (Washington, DC), Hatch project 1006519 to P. M. Fricke.

\section{REFERENCES}

Ambrose, J. D., M. Drost, R. L. Monson, J. J. Rutledge, M. L. Leibfried-Rutledge, M.-J. Thatcher, T. Kassa, M. Binelli, P. J. Hansen, P. J. Chenoweth, and W. W. Thatcher. 1999. Efficacy of timed embryo transfer with fresh and frozen in vitro produced embryos to increase pregnancy rates in heat-stressed dairy cattle. J. Dairy Sci. 82:2369-2376.

American Embryo Transfer Association (AETA). 2018. Annual reports. Accessed Jun. 30, 2018. https://www.aeta.org/survey.asp.

Araujo, R. R., O. J. Ginther, J. C. Ferreira, M. M. Palhão, M. A. Beg, and M. C. Wiltbank. 2009. Role of follicular estradiol-17beta in timing of luteolysis in heifers. Biol. Reprod. 81:426-437.

Bertolini, M., S. W. Beam, H. Shim, L. R. Bertolini, A. L. Moyer, T. R. Famula, and G. B. Anderson. 2002. Growth, development, and gene expression by in vivo- and in vitro-produced Day 7 and 16 bovine embryos. Mol. Reprod. Dev. 63:318-328.

Block, J., and P. J. Hansen. 2007. Interaction between season and culture with insulin-like growth factor-1 on survival of in vitro produced embryos following transfer to lactating dairy cows. Theriogenology 67:1518-1529.

Bodmer, M., F. Janett, M. Hässig, N. den Daas, P. Reichert, and R. Thun. 2005. Fertility in heifers and cows after low dose insemination with sex-sorted and non-sorted sperm under field conditions. Theriogenology 64:1647-1655.

Bombardelli, G. D., H. F. Soares, and R. C. Chebel. 2016. Time of insemination relative to reaching activity threshold is associated with pregnancy risk when using sex-sorted semen for lactating Jersey cows. Theriogenology 85:533-539.

Breuel, K. F., J. C. Spitzer, and D. M. Henricks. 1989. Systemic progesterone concentration following human chorionic gonadotropin administration at various times during the estrous cycle in beef heifers. J. Anim. Sci. 67:1564-1572.

Breuel, K. F., J. C. Spitzer, C. E. Thompson, and J. F. Breuel. 1990. First-service pregnancy rate in beef heifers as influenced by human chorionic gonadotropin administration before and/or after breeding. Theriogenology 34:139-145.

Cabrera, V. E. 2012. A simple formulation and solution to the replacement problem: A practical tool to assess the economic cow value, the value of a new pregnancy, and the cost of a pregnancy loss. J. Dairy Sci. 95:4683-4698

Carter, F., N. Forde, P. Duffy, M. Wade, T. Fair, M. A. Crowe, A. C O. Evans, D. A. Kenny, J. F. Roche, and P. Lonergan. 2008. Effect of increasing progesterone concentration from day 3 of pregnancy on subsequent embryo survival and development in beef heifers. Reprod. Fertil. Dev. 20:368-375. 
Carvalho, P. D., C. C. Consentini, S. R. Weaver, R. V. Barleta, L. L. Hernandez, and P. M. Fricke. 2017. Temporarily decreasing progesterone after timed artificial insemination decreased expression of interferon-tau stimulated gene 15 (ISG15) in blood leukocytes, serum pregnancy-specific protein $\mathrm{B}$ concentrations, and embryo size in lactating Holstein cows. J. Dairy Sci. 100:3233-3242.

Chagas e Silva, J., and L. Lopes da Costa. 2005. Luteotrophic influence of early bovine embryos and the relationship between plasma progesterone concentrations and embryo survival. Theriogenology 64:49-60.

Chagas e Silva, J., L. Lopes da Costa, and J. Robalo Silva. 2002. Plasma progesterone profiles and factors affecting embryo-fetal mortality following embryo transfer in dairy cattle. Theriogenology 58:51-59.

Chebel, R. C., D. G. B. Demetrio, and J. Metzger. 2008. Factors affecting success of embryo collection and transfer in large dairy herds. Theriogenology 69:98-106.

Chebel, R. C., F. S. Guagnini, J. E. P. Santos, J. P. Fetrow, and J. R. Lima. 2010. Sex-sorted semen for dairy heifers: Effects on reproductive and lactational performances. J. Dairy Sci. 93:2496-2507.

Dahlen, C. R., S. L. Bird, C. A. Martel, K. C. Olson, J. S. Stevenson, and G. C. Lamb. 2010. Administration of human chorionic gonadotropin 7 days after fixed-time artificial insemination of suckled beef cows. J. Anim. Sci. 88:2337-2345.

De Rensis, F., F. López-Gatius, I. García-Ispierto, and M. Techakumpu. 2010. Clinical use of human chorionic gonadotropin in dairy cows: an update. Theriogenology 73:1001-1008.

DeJarnette, J. M., R. L. Nebel, and C. E. Marshall. 2009. Evaluating the success of sex-sorted semen in US dairy herds from on farm records. Theriogenology 71:49-58.

Diaz, T., E. J. P. Schmitt, R. L. De La Sota, M. J. Thatcher, and W. W. Thatcher. 1998. Human chorionic gonadotropin-induced alterations in ovarian follicular dynamics during the estrous cycle of heifers. J. Anim. Sci. 76:1929-1936.

Farin, C. E., K. Imakawa, T. R. Hansen, J. J. McDonnell, C. N. Murphy, P. W. Farin, and R. M. Roberts. 1990. Expression of trophoblastic interferon genes in sheep and cattle. Biol. Reprod. 43:210-218.

Forde, N., F. Carter, T. Fair, M. A. Crowe, A. C. O. Evans, T. E. Spencer, F. W. Bazer, R. McBride, M. P. Boland, P. O'Gaora, P. Lonergan, and J. F. Roche. 2009. Progesterone-regulated changes in endometrial gene expression contribute to advanced conceptus development in Cattle. Biol. Reprod. 81:784-794.

Forde, N., J. P. Mehta, M. Minten, M. A. Crowe, J. F. Roche, T. E. Spencer, and P. Lonergan. 2012. Effects of low progesterone on the endometrial transcriptome in cattle. Biol. Reprod. 87:124.

Funston, R. N., R. J. Lipsey, T. W. Geary, and A. J. Roberts. 2005 Effect of administration of human chorionic gonadotropin after artificial insemination on concentrations of progesterone and conception rates in beef heifers. J. Anim. Sci. 83:1403-1405.

Galvão, K. N., J. E. P. Santos, A. C. Coscioni, S. O. Juchem, R. C. Chebel, W. M. Sischo, and M. Villasenor. 2006. Embryo survival from Gossypol-fed heifers after transfer to lactating cows treated with human chorionic gonadotropin. J. Dairy Sci. 89:2056-2064.

Garcia-Guerra, A., R. V. Sala, G. M. Baez, M. Fosado, L. F. Melo, J. C. L. Motta, L. Leffers, E. A. Walleser, J. C. Ochoa, J. F. Moreno, and M. C. Wiltbank. 2015. Treatment with GnRH on day 5 reduces pregnancy loss in heifers receiving in vitro-produced expanded blastocysts. Reprod. Fertil. Dev. 28:185-186.

Ginther, O. J., L. Knoph, and J. P. Kastelic. 1989. Temporal associations among ovarian events in cattle during oestrous cycles with two and three follicular waves. J. Reprod. Fertil. 87:223-230.

Giordano, J. O., J. N. Guenther, G. Lopes Jr., and P. M. Fricke. 2012. Changes in serum pregnancy-associated glycoprotein, pregnancyspecific protein $\mathrm{B}$, and progesterone concentrations before and after induction of pregnancy loss in lactating dairy cows. J. Dairy Sci. 95:683-697.

Gosálvez, J., M. A. Ramirez, C. López-Fernández, F. Crespo, K. M. Evans, M. E. Kjelland, and J. F. Moreno. 2011. Sex-sorted bovine spermatozoa and DNA damage: II. Dynamic features. Theriogenology 75:206-211.
Han, H., K. J. Austin, L. A. Rempel, and T. R. Hansen. 2006. Low blood ISG15 mRNA and progesterone levels are predictive of nonpregnant dairy cows. J. Endocrinol. 191:505-512.

Hasler, J. F. 2001. Factors affecting frozen and fresh embryo transfer and pregnancy rates in cattle. Theriogenology 56:1401-1415.

Humblot, P. 2001. Use of pregnancy specific proteins and progesterone assays to monitor pregnancy and determine the timing, frequencies and sources of embryonic mortality in ruminants. Theriogenology $56: 1417-1433$

Humblot, F., S. Camous, J. Martal, J. Charlerey, N. Jeanguyot, M. Thibier, and R. G. Sasser. 1988. Pregnancy specific protein B, progesterone concentrations and embryonic mortality during early pregnancy in dairy cows. J. Reprod. Fertil. 83:215-223.

Kubisch, H. M., M. A. Larson, and R. M. Roberts. 1998. Relationship between age of blastocyst formation and interferon- $\tau$ secretion by in vitro-derived bovine embryos. Mol. Reprod. Dev. 49:254-260.

Larson, J. E., G. C. Lamb, J. S. Stevenson, S. K. Johnson, M. L. Day, T. W. Geary, D. J. Kesler, J. M. DeJarnette, F. N. Schrick, A. DiCostanzo, and J. D. Arseneau. 2006. Synchronization of estrus in suckled beef cows for detected estrus and artificial insemination and timed artificial insemination using gonadotropin-releasing hormone, prostaglandin $\mathrm{F}_{2 \alpha}$, and progesterone. J. Anim. Sci. 84:332-342.

Lima, F. S., E. S. Ribeiro, R. S. Bisinotto, L. F. Greco, N. Martinez, M. Amstalden, W. W. Thatcher, and J. E. P. Santos. 2013. Hormonal manipulations in the 5-day timed artificial insemination protocol to optimize estrous cycle synchrony and fertility in dairy heifers. J. Dairy Sci. 96:7054-7065.

Livak, K. J., and T. D. Schmittgen. 2001. Analysis of relative gene expression data using real-time quantitative PCR and the $2^{-\Delta \Delta \mathrm{ct}}$ method. Methods 25:402-408.

Lopes-da-Costa, L., J. Chagas e Silva, M. C. Deloche, N. Jeanguyot, P. Humblot, and A. E. M. Horta. 2011. Effects of embryo size at transfer (whole versus demi) and early pregnancy progesterone supplementation on embryo growth and pregnancy-specific protein bovine concentrations in recipient dairy heifers. Theriogenology $76: 522-531$.

Macmillan, K. L., V. K. Taufa, D. R. Barnes, A. M. Day, and R. Henry. 1988. Detecting estrus in synchronized heifers-using tailpaint and an aerosol raddle. Theriogenology 30:1099-1114.

Mann, G. E., M. D. Fray, and G. E. Lamming. 2006. Effects of time of progesterone supplementation on embryo development and interferon- $\tau$ production in the cow. Vet. J. 171:500-503.

Mann, G. E., and G. E. Lamming. 1999. The influence of progesterone during early pregnancy in cattle. Reprod. Domest. Anim. $34: 269-274$.

Mann, G. E., and G. E. Lamming. 2001. Relationship between maternal endocrine environment, early embryo development and inhibition of the luteolytic mechanism in cows. Reproduction 121:175180.

Mann, G. E., G. E. Lamming, R. S. Robinson, and D. C. Wathes. 1999. The regulation of interferon- $\tau$ production and uterine hormone receptors during early pregnancy. J. Reprod. Fertil. Suppl. $54: 317-328$.

Matsuyama, S., T. Kojima, S. Kato, and K. Kimura. 2012. Relationship between quantity of IFNT estimated by IFN-stimulated gene expression in peripheral blood mononuclear cells and bovine embryonic mortality after AI or ET. Reprod. Biol. Endocrinol. 10:21.

Nascimento, A. B., R. W. Bender, A. H. Souza, H. Ayres, R. R. Araujo, J. N. Guenther, R. Sartori, and M. C. Wiltbank. 2013. Effect of treatment with human chorionic gonadotropin on day 5 after timed artificial insemination on fertility of lactating dairy cows. J. Dairy Sci. 96:2873-2882.

Nishigai, M., H. Kamomae, T. Tanaka, and Y. Kaneda. 2002. Improvement of pregnancy rate in Japanese Black cows by administration of hCG to recipients of transferred frozen-thawed embryos. Theriogenology 58:1597-1606.

Pereira, M. H. C., C. P. Sanches, T. G. Guida, A. D. P. Rodrigues, F. L. Aragon, M. B. Veras, P. T. Borges, M. C. Wiltbank, and J. L. M. Vasconcelos. 2013. Timing of prostaglandin $\mathrm{F}_{2 \alpha}$ treatment in an estrogen-based protocol for timed artificial insemina- 
tion or timed embryo transfer in lactating dairy cows. J. Dairy Sci. 96:2837-2846.

Pereira, M. H. C., M. C. Wiltbank, and J. L. M. Vasconcelos. 2016. Expression of estrus improves fertility and decreases pregnancy losses in lactating dairy cows that receive artificial insemination or embryo transfer. J. Dairy Sci. 99:2237-2247.

Pierce, J. G., and T. F. Parsons. 1981. Glycoprotein hormones: Structure and function. Annu. Rev. Biochem. 50:465-495.

Price, C. A., and R. Webb. 1989. Ovarian response to hCG treatment during the estrous-cycle in heifers. J. Reprod. Fertil. 86:303-308.

Ricci, A., P. D. Carvalho, M. C. Amundson, and P. M. Fricke. 2017. Characterization of luteal dynamics in lactating Holstein cows for 32 days after synchronization of ovulation and timed artificial insemination. J. Dairy Sci. 100:9851-9860.

Rizos, D., S. Scully, A. K. Kelly, A. D. Ealy, R. Moros, P. Duffy, A. Al Naib, N. Forde, and P. Lonergan. 2012. Effects of human chorionic gonadotrophin administration on Day 5 after oestrus on corpus luteum characteristics, circulating progesterone and conceptus elongation in cattle. Reprod. Fertil. Dev. 24:472-481.

Sá Filho, M. F., H. Ayres, R. M. Ferreira, M. Nichi, M. Fosado, E. P. Campos Filho, and P. S. Baruselli. 2010. Strategies to improve pregnancy per insemination using sex-sorted semen in dairy heifers detected in estrus. Theriogenology 74:1636-1642.

Sales, J. N. S., K. A. L. Neves, A. H. Souza, G. A. Crepaldi, R. V. Sala, M. Fosado, E. P. Campos Filho, M. de Faria, M. F. Sá Filho, and P. S. Baruselli. 2011. Timing of insemination and fertility in dairy and beef cattle receiving timed artificial insemination using sex-sorted sperm. Theriogenology 76:427-435

Santos, J. E. P., W. W. Thatcher, L. Pool, and M. W. Overton. 2001. Effect of human chorionic gonadotropin on luteal function and reproductive performance of high-producing lactating Holstein dairy cows. J. Anim. Sci. 79:2881-2894.

Sartori, R., J. M. Haughlan, R. D. Shaver, G. J. M. Rosa, and M. C. Wiltbank. 2004. Comparison of ovarian function and circulating steroids in estrous cycles of Holstein heifers and lactating cows. J. Dairy Sci. 87:905-920.

Sasser, R. G., C. A. Ruder, K. A. Ivani, J. E. Butler, and W. C. Hamilton. 1986. Detection of pregnancy by radioimmunoassay of a novel pregnancy-specific protein in serum of cows and a profile of serum concentration during gestation. Biol. Reprod. 35:936-942.

Schmitt, E. J. P., T. Diaz, C. M. Barros, R. L. de la Sota, M. Drost, E. W. Fredriksson, C. R. Staples, R. Thorner, and W. W. Thatcher. 1996. Differential response of the luteal phase and fertility in cattle following ovulation of the first-wave follicle with human chorionic gonadotropin or an agonist of gonadotropin-releasing hormone. J. Anim. Sci. 74:1074-1083.

Seidel, G. E. Jr. 2014. Update on sexed semen technology in cattle. Animal 8:160-164.

Sianangama, P. C., and R. Rajamahendran. 1992. Effect of human chorionic gonadotropin administered at specific times following breeding on milk progesterone and pregnancy in cows. Theriogenology 38:85-96.
Spencer, T. E., and F. W. Bazer. 2004. Conceptus signals for establishment and maintenance of pregnancy. Reprod. Biol. Endocrinol $2: 49$.

Spencer, T. E., G. A. Johnson, F. W. Bazer, R. C. Burghardt, and M. Palmarini. 2007. Pregnancy recognition and conceptus implantation in domestic ruminants: roles of progesterone, interferons and endogenous retroviruses. Reprod. Fertil. Dev. 19:65-78.

Stevenson, J. S., M. A. Portaluppi, D. E. Tenhouse, A. Lloyd, D. R. Eborn, S. Kacuba, and J. M. DeJarnette. 2007. Interventions after artificial insemination: Conception rates, pregnancy survival, and ovarian responses to gonadotropin-releasing hormone, human chorionic gonadotropin, and progesterone. J. Dairy Sci. 90:331-340.

Stringfellow, D. A., and M. D. Givens. 2010. Manual of the International Embryo Transfer Society: A Procedural Guide and General Information for the Use of Embryo Transfer Technology Emphasizing Sanitary Precautions. 4th ed. International Embryo Transfer Society, Champaign, IL.

Stubbings, R. B., and J. S. Walton. 1986. Relationship between plasma progesterone concentrations and pregnancy rates in cattle receiving either fresh or previously frozen embryos. Theriogenology $26: 145-155$

Thatcher, W. W., F. Moreira, J. E. P. Santos, R. C. Mattos, F. L. Lopes, S. M. Pancarci, and C. A. Risco. 2001. Effects of hormonal treatments on reproductive performance and embryo production. Theriogenology 55:75-89.

Torres, A., J. Chagas e Silva, M. C. Deloche, P. Humblot, A. E. M. Horta, and L. Lopes-da-Costa. 2013a. Secondary corpora lutea induced by hCG treatment enhanced demi-embryo survival in lactating high-yielding dairy cows. Reprod. Domest. Anim. 48:643-650.

Torres, A., J. Chagas e Silva, P. Diniz, and L. Lopes-da-Costa. 2013b. Evaluation of treatments with hCG and carprofen at embryo transfer in a demi-embryo and recipient virgin heifer model. Animal 7:1317-1322.

Vasconcelos, J. L. M., R. Sartori, H. N. Oliveira, J. G. Guenther, and M. C. Wiltbank. 2001. Reduction in size of the ovulatory follicle reduces subsequent luteal size and pregnancy rate. Theriogenology $56: 307-314$

Wahome, J. N., M. J. Stuart, and A. E. Smith. 1985. Insemination management for a one-injection prostaglandin $\mathrm{F}_{2 \alpha}$ synchronization system. II. One versus two inseminations following detection of estrus. Theriogenology 24:501-507.

Wallace, L. D., C. A. Breiner, R. A. Breiner, A. R. Spell, J. A. Carter, G. C. Lamb, and J. S. Stevenson. 2011. Administration of human chorionic gonadotropin at embryo transfer induced ovulation of a first wave dominant follicle, and increased progesterone and transfer pregnancy rates. Theriogenology 75:1506-1515.

Wiltbank, M. C., G. M. Baez, A. Garcia-Guerra, M. Z. Toledo, P. L. J. Monteiro, L. F. Melo, J. C. Ochoa, J. E. P. Santos, and R. Sartori 2016. Pivotal periods for pregnancy loss during the first trimester of gestation in lactating dairy cows. Theriogenology 86:239-253. 